\title{
Normative Study of the Recognition Words Written Test "P1" for Moroccan Children Aged 7.5 - 11.5 Years
}

\author{
Ahlam El Moutez, Mostapha El Alaoui Faris, Maria Benabdejlil \\ Department of Neurology and Neuropsychology A, Faculty of Medicine and Pharmacy, Rabat, Mohammed 5 University, Rabat, \\ Morocco \\ Email: mustapha.elalaouifaris@gmail.com, benab.maria@yahoo.fr
}

How to cite this paper: El Moutez, A., El Alaoui Faris, M., \& Benabdejlil, M. (2018). Normative Study of the Recognition Words Written Test "P1" for Moroccan Children Aged 7.5 - 11.5 Years. Psychology, 9, 13971411.

https://doi.org/10.4236/psych.2018.96085

Received: April 14, 2018

Accepted: June 26, 2018

Published: June 29, 2018

Copyright $\odot 2018$ by authors and Scientific Research Publishing Inc. This work is licensed under the Creative Commons Attribution International License (CC BY 4.0).

http://creativecommons.org/licenses/by/4.0/

(c) (i) Open Access

\begin{abstract}
Objective: The objective of the present study is to provide the Moroccan and Arab healthcare professional with a tool for assessing the Arabic language reading, adapted to their context and taking into accounts the characteristics of the Arab language structure. At the same time, to extract the essential standards of the test for Moroccan children, these standards would make it easier to detect learning disabilities related to the treatment of the written language. Method: The test was applied individually to a random sample of 116 children from different age groups ranging from seven to eleven years, these are children from different social status and different types of schools in Rabat, capital of Morocco. Our selection criterion is that the child presents no psychological tracking, speech therapy or psychomotor therapy. Results: The performance of the psychometric properties of the test, the reliability, the validity, and the standards provide efficacy the effectiveness of its application and its generalization in situations where language processing is needed. Conclusion: This test can be used by the doctor, the neuropsychologist or the speech therapist in order to be able to establish a diagnosis concerning the presence or absence of learning disabilities in relation to the treatment of written language. The diagnosis could actually lead neuropsychologists or speech therapists, in the care of children with difficulty of written language treatment.
\end{abstract}

\section{Keywords}

Learning Disabilities, Assessment, Arabic Language, Vocalization,

Recognition Written Word, Reading, Developmental Dyslexia, Children, Norms

\section{Introduction}

The main objective of our study is to allow an objective evaluation of dyslexia 
through the treatment of Arabic language and to elaborate reading norms, specific to the population of Arabic-speaking children attending school.

Morocco presents a tri-linguistic context, Arabic, French and Berber. The mother tongue of most children is Arabic.

School programs are taught more in Arabic than in French. Berber language not yet introduced into school curricula.

On the other hand, health professionals are not equipped with tools to evaluate the treatment of the Arabic language, adapted to the Moroccan population. The diagnoses made are based solely on clinical opinion, not standards.

Developmental dyslexia is a specific impairment in acquisition of reading skills that is not solely accounted by mental age, visual acuity problems or inadequate schooling (Grégoire \& Laveault, 2014; Forum Mondial sur la dyslexie, 2010). It is a reading disorder in children and adults identified in part by difficulties with single-word reading and spelling (Fletcher, 2009; Reid Lyon, E. Shaywitz, \& Shaywitz, 2003). A hypothesis, put forward by D. L. Share in 1995 (Share, 1995) and This mastery of decoding is the sine qua non for learning to read, so the difficulty of identifying the written word is considered to be the main source of failure in reading (Ziegler, Perry, \& Zorzi, 2014). Reading activity relies mainly on the ability to identify the written word as a form of orthography with meaning (Marec-Breton, Gombert, \& Colé, 2005) and phonology (Romdhane, Gombert, \& Belajouza, 2003). The efficiency of this process identification, its accuracy and speed, explain the differences in performance (Geva, Wade-Woolley, \& Shany, 1997). The word identification process assumes the existence of an orthographic mental lexicon that is constructed and enriched as the child advances in written language learning (Snowling, 1988). In this mental lexicon we have all the phonological, graphological, semantic and syntactic representations of the words frequently used by the subject (Zagar, Fayol, Gombert, Lecoq, \& Sprenger-Charolles, 1994).

Thus, given the importance of this reading task and its evaluation, it is essential for the detection difficulty in processing written language or dyslexia, for all languages. In the Moroccan context, there is no suitable instrument for detecting dyslexia in the Arabic language.

According to DSM5, Diagnostic and Statistical Manual, (APA, 2013), dyslexia has been incorporated into the definition of Specific Learning Disorder. It is consider as the incapacity of children, of normal intelligence and without neurological disorder, to acquire the specific skills to the treatment of written language, adapted to their age.

Then, if we admit that the symptoms of dyslexia are manifest mainly in word recognition, decoding, especially its speed and accuracy, we propose the test of reading of isolated words, designated by P1. It measures the quality of the phonological decoding of Arabic words. We were inspired by the work of Ecalle (Écalle, 2010; Jacquier-Roux, Valdois, \& Zorman, 2002; Sprenger-Charolles, Colé, Béchennec, \& Kipffer-Piquard, 2005; Abo Ras, Kozou, \& Abdou, 2008). 
This test evaluates three types of reading, based on the vocalization of the stimulus or not (for word) and reading no word (Goswami, Ziegler, Dalton, \& Schneider, 2003; Abu-Rabia, 1996; Abu-Rabia, 1998; Ammar, 1998; Ammar, 2002):

1) P11 phonological decoding of vocalized words, associated with its recognition.

2) P12 recognition and access to orthographic stock with non-vocalized words.

3) P13 phonological decoding of vocalized pseudo-words.

In sum, this test highlights the type of dominant functional dissociation in reading, which can be analytical, lexical or mixed.

The words of each subtest are presented in a list of 25 words (Table 2). Those of the P11 and P12 subtests were extracted from the school reading books, retaining the most frequent ones. The criterion of choice of words takes into account some characteristics of the Arabic language (determination, double vocalization, gemination, elongation and isolated vowel). The P13, subtest of pseudo words, were constructed from the first two lists, either by changing a letter or by reversing the syllables of a single word. In each list, the word length is increasing in terms of syllables.

The measurements of the three subtests correspond to the number of words correctly read per minute. Thus his administration provides 3 scores with 3 corresponding times.

Then, in this study, we are interested in the reading aspect separated from other abilities in relation to written language processing. We study the evaluation results of reading the isolated words by the $\mathrm{P} 1$ test. The analysis and discussion of the results led us to confirm the performance of the P1 test and to establish standards regarding the quality of statistical indices of reliability, validity and standardization. We will then discuss the standards and thresholds obtained as well as the different possible applications.

\section{Methods}

\subsection{Study Design}

The research team obtained the approval of the Ministry of National Education to administer the test to schoolchildren. The P1 test was applied individually to the sample by the author, with the assistance of the research team of the Faculty of Medicine of Rabat and school's pedagogical team. The application process lasted nearly six months.

\subsection{Participants}

This study focuses on a population of Moroccan children, Arabic speaking, schooled and aged from 7 to 12 years. A random sample of 120 children was selected from four schools in the Rabat city. The criteria for selection of the sample: 
1) The grade is from second to sixth grade of the primary school (CE2 to CE6).

2) As many boys as girls per level grade.

3) As many children in private schools than in public schools

4) from different social backgrounds

Exclusion criteria:

1) without cognitive or psychic developmental disorders,

2) without psychological, psychomotor or speech therapy.

The sampling is based on the random selection of children, in each school by grade, according to the mentioned criteria. It is noted that four of them had psychological difficulties, they were referred to the doctor of the school.

Age is determined by the number of months at the time of assessment. We propose five age groups, with a 12-month step. This distribution is consistent with the school level of the children (Table 1).

\subsection{Test Methods}

The experimentation of the test was carried out in several stages:

1) Definition of the target population and selection of the sample (see above).

2) Drafting of material (Table 2):

a) Choice of words and pseudo-words.

b) Elaboration of instructions

c) Preparation of written materials for children and for examiners

d) Organization of test administration with schools

3) Pre-administration to validate instructions and materials:

a) Some non-vocalized words from the beginning of list 2 were changed because they were unfamiliar to the majority of children in the first levels.

b) Instructions and presentation have been maintained.

4) Effective administration for data collection.

5) Re-test to confirm the validity of the test (36 children).

6) Administration the test to children with learning disabilities related written language in order to confirm the experimental validity.

Table 1. The characteristics of the sampling.

\begin{tabular}{|c|c|c|c|c|c|c|c|c|c|c|c|c|c|}
\hline \multirow[t]{2}{*}{ Age } & \multirow{2}{*}{$\begin{array}{c}\text { Number } \\
\text { Total }\end{array}$} & \multicolumn{2}{|c|}{ CE2 } & \multicolumn{2}{|c|}{ CE3 } & \multicolumn{2}{|c|}{ CE4 } & \multicolumn{2}{|c|}{ CE5 } & \multicolumn{2}{|c|}{ CE6 } & \multicolumn{2}{|c|}{ Tot } \\
\hline & & G & B & G & B & G & B & G & B & G & B & $\mathbf{P}$ & V \\
\hline 7.5 & 22 & 10 & 12 & & & & & & & & & 10 & 12 \\
\hline 8.5 & 21 & 2 & & 10 & 9 & & & & & & & 12 & 9 \\
\hline 9.5 & 25 & & & 2 & 2 & 11 & 10 & & & & & 13 & 12 \\
\hline 10.5 & 22 & & & & & & 2 & 9 & 11 & & & 11 & 11 \\
\hline \multirow[t]{2}{*}{11.5} & 26 & & & & & & & 3 & 1 & 11 & 11 & 12 & 14 \\
\hline & 116 & 12 & 12 & 12 & 11 & 11 & 12 & 11 & 12 & 11 & 11 & 58 & 58 \\
\hline
\end{tabular}

G: girl, B: boys, P: public, V: private. 
Table 2. Lists of words (list 1 and list 2) and pseudo-words (list 3).

\begin{tabular}{|c|c|c|c|c|}
\hline \multirow{2}{*}{ 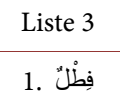 } & \multicolumn{2}{|c|}{ Liste 2} & \multicolumn{2}{|c|}{ Liste 1} \\
\hline & 1. Light & نـور .1 & 1. Bag & كِيـسن" .1 \\
\hline 2. جُبْز " & 2. Door & 2. 2. & 2. Mouth & 2. فَ \\
\hline 3. غلَّ . & 3. Elephant & 3. فيـل & 3. Grapes & 3. \\
\hline 4. مِنْتُ & 4. Sky & سمـاء .4 & 4. classroom & 4فـــــــن \\
\hline 5رجاجٌ ز رُج & 5. Dog & 5لب 5. & 5. Bucket & 5. دَلْوُو \\
\hline 6. فارِبٌ & 6. cakes & حلوى .6 & 6. Alklum & 6. آلْنَـَنَــرن \\
\hline 7. طِقَّة & 7. Cup & كأس .7. & 7. Shelter & 7. 7َسَأُوَى \\
\hline 8. فائطٌ & 8. Hours & 8ــاعـة 8 & 8. Walls & 8. آلَحَائِطُ \\
\hline 9. صِنْديلٌ & 9. Snow & 9. ثلج & 9. Glass & 9. زُجَـابْ \\
\hline 10. مَفِينة & 10. Professor & 10. الأســــــاذ & 10. Fish & 10. سَـنَنَعَة \\
\hline 11. غِمارَة & 11. Pearl & لــؤلــؤ .11 & 11. Thieves & 11. اللاُعُســوصن \\
\hline 12. كُنْوقُ & 12. The mosque & 12. المســـــــ & 12. Qnafd & 12. قُ 1َنْفُدْ \\
\hline 13. قائِرَةٌ & 13. Box & 13. صندوق & 13. Fisherman & 13. صَـــنَّ \\
\hline سُبْتَانٌ .14 & 14. Garden & بستان .14 & 14. Heads & آلـرُؤوسن .14 \\
\hline 15. نائَدة & 15. Cat & قطة .15 & 15. Aircraft & 15. آلطونـائِرَزة \\
\hline سُلَخْفاةٌ . & 16. Turtle & سلحفاة .16 & 16. Towel & 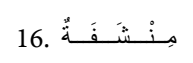 \\
\hline 17. مِنْشَقَة & 17. Chair & كرسي .17 & 17. Multicolored & 17. مُزَرْكَشَ" \\
\hline 18. سَنْدَلِبِ & 18. Schoolbag & محفظة .18 & 18. Greenness & 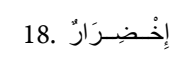 \\
\hline 19. غَيَّارَة & 19. It & فإنـه .19 & 19. the distraction & اللهَهْْوِ .19. \\
\hline 20. مِفحَظَة & 20. You are & أنتن .20 & 20. An invention & 20. آلإخـــتــر اعُع \\
\hline سُرْكِيّ" .21 & $\begin{array}{l}\text { 21. His Refrige- } \\
\text { rator }\end{array}$ & 21. ثلاجتها & 21. Break & 21. إِسْنَــرَاحَــة \\
\hline 22. مِفْلَمَة & 22. Clinic & 22. مستوصف & 22. Terminology & 22. مُصنطَـَنَاته \\
\hline نَنََّارَةُ . & 23. emerald & زمردة .23 & 23. Cylinders & 23. أُسْطُوَوَانَاتَّ \\
\hline 24. قُقَََّحَة & 24. His apple & 24. تفاحته & 24. Their parents & 24. آبَـاوُهُهـنَ \\
\hline 25. تَنَّاجَة & 25. Their ship & سفينتهم .25 & 25. Nine hundred & 25. تِسْعُعِيَنة \\
\hline
\end{tabular}

\subsection{Analysis}

1) Determination of standards using the $z$ score:

a) $\mathrm{z}<-2$ deep reading disorder;

b) $\mathrm{z} \in[-2,-1]$ reading disorder;

c) $\mathrm{z} \in[-1,0]$ at risk;

d) $\mathrm{z} \geq 0$ normal.

2) To appreciate the performance of the P1 test and its components, it's necessary to calculate and analyze some important statistical indices such as the smallest and highest measures, the average, the standard deviation of the scores, the skewnes, and kurtosis of their distribution (Table 3 and Table 4) (Figures 1-3). 
Table 3. Statistical indices of P1 measurements.

\begin{tabular}{ccccccccc}
\hline Age & Number & least & Mean & highest & St & St/mean & Skewness & Kurtosis \\
\hline 7.5 & 22 & 9.4 & 18.7 & 33.0 & 5.61 & $30 \%$ & 0.47 & 0.81 \\
8.5 & 21 & 15.0 & 29.0 & 45.3 & 8.38 & $29 \%$ & 0.84 & 0.54 \\
9.5 & 25 & 22.1 & 35.1 & 53.1 & 8.86 & $25 \%$ & 0.21 & 0.08 \\
10.5 & 22 & 21.4 & 41.6 & 62.7 & 10.92 & $26 \%$ & 0.18 & -0.72 \\
11.5 & 26 & 26.8 & 52.2 & 70.1 & 11.83 & $23 \%$ & -0.05 & 0.29 \\
Total & 116 & $\mathbf{9 . 4}$ & $\mathbf{3 5 . 9}$ & $\mathbf{7 0 . 1}$ & $\mathbf{1 4 . 7 7}$ & $\mathbf{4 1 \%}$ & & \\
\hline
\end{tabular}

Table 4. Statistical indices of the subtests P11. P12 and P13 measurements.

\begin{tabular}{cccccccccc}
\hline & \multicolumn{3}{c}{ P1 } & \multicolumn{3}{c}{ P11: MoVoc } & \multicolumn{2}{c}{ P12:MonVoc } & \multicolumn{2}{c}{ P13:PsMo } \\
\hline Age & Number & Mean & St & Mean & St & Mean & St & Mean & St \\
\hline 7.5 & 22 & 18.7 & 5.6 & 17.9 & 4.8 & 19.4 & 8.7 & $\mathbf{1 8 . 6}$ & 4.8 \\
8.5 & 21 & 29.0 & 8.4 & 27.1 & 8.7 & 32.4 & 11.4 & 27.5 & 11.9 \\
9.5 & 25 & 35.1 & 8.9 & 32.5 & 10.0 & 42.6 & 11.2 & 30.3 & 8.7 \\
10.5 & 22 & 41.6 & 10.9 & 41.7 & 12.5 & 48.7 & 13.6 & 34.3 & 9.0 \\
11.5 & 26 & 52.2 & 11.8 & $\mathbf{5 1 . 9}$ & 13.1 & $\mathbf{6 4 . 3}$ & 15.2 & $\mathbf{4 0 . 3}$ & 9.6 \\
Total & 116 & $\mathbf{3 5 . 9}$ & $\mathbf{1 4 . 8}$ & $\mathbf{3 4 . 9}$ & $\mathbf{1 5 . 7}$ & $\mathbf{4 2 . 4}$ & $\mathbf{1 9 . 5}$ & $\mathbf{3 0 . 6}$ & $\mathbf{1 1 . 5}$ \\
\hline
\end{tabular}

MoVoc: Vocalized word; MonVoc: unvocalized word; PsMo: pseudo word.

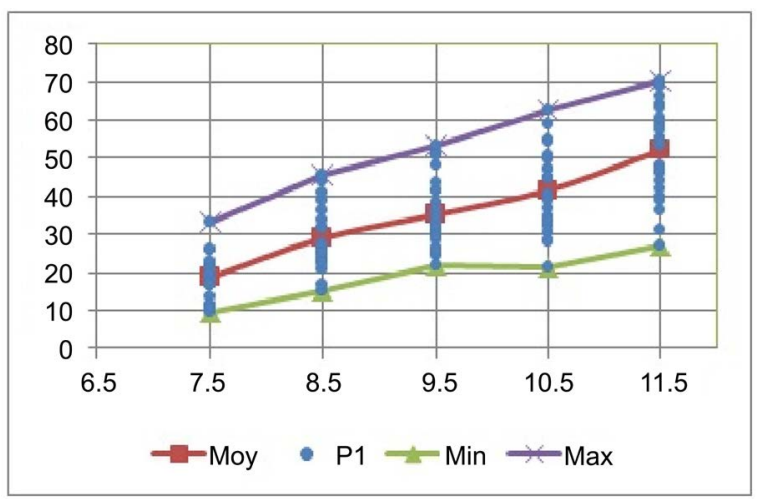

Figure 1. Cloud and statistical indeces of P1 measurements.

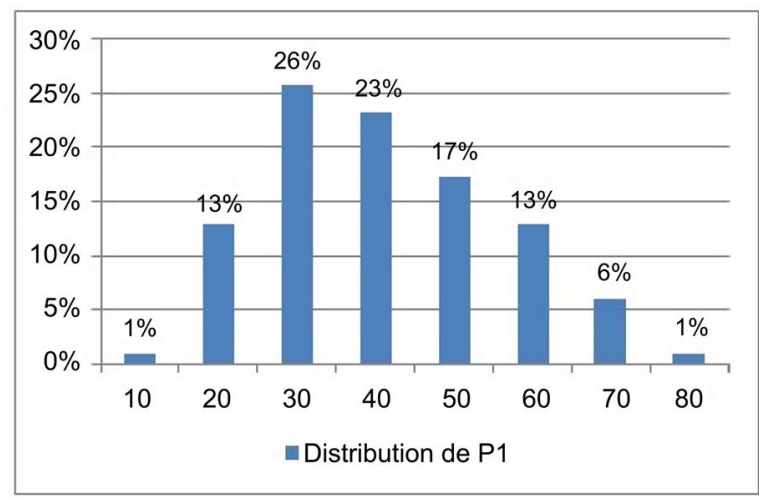

Figure 2. Distribution of P1 measurements. 

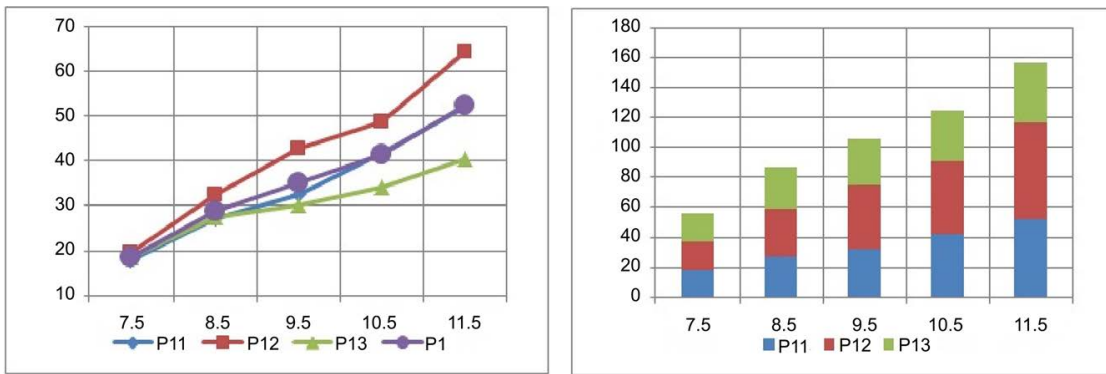

Figure 3. Comparative evolution of reading measurements P11, P12, P13.

3) The performance of the psychometric properties of the test was analyzed by the application of reliability and validity methods (Grégoire \& Laveault, 2014): Alpha Cronbach coefficient, split half, internal correlation, and retest (Table 5 and Table 6) (Figure 5 and Figure 6).

4) The standards are determined for P1 from the percentiles and for the subtests from the thresholds calculated from means by deducting a unit of standard deviation (Table 7 and Table 8).

\section{Results}

\section{1) Analysis of Recognition words test results $P 1$}

The overall performance of the readingP1 test increases steadily from 18.7 to 52.2 words per minute, as age increases (Table 3, Figure 1). The Moroccan child improves his reading, annually about 6.6 words per minute. This value integrates 3 aspects of reading: vocalized words, non-vocalized words and pseudo words (Table 4). The overall performance of this measure is not sufficient to confirm the absence of a disorder. Thus, the separate analysis of the results of the 3 subtests is indispensable in a situation of deficit. The values are not very concentrated around the averages and record a dispersion of approximately $27 \%$ of the averages of the measurements.

As shown in Table 3, the skewness and kurtosis values were within acceptable range of normality.

\section{2) Analysis of the 3 aspects of recognition words}

The results of the three subtests relating to the reading are presented in the Table 4. We note:

The averages of each subtest measurements increases steadily as age increases. Their values are not very concentrated and record dispersion about $30 \%$ of their averages. The graphical representation highlights the layout and evolution of the three types of curves (P11, P12 and P13).

The 3 performances of readings are equivalent for the children of the first 7.5 slice. The reading of non-vocalized words (P12) is acquired more quickly with age compared to other types of reading (with vocalizations). In fact, the older the age, the more children learn to read non-vocalized words rather than vocalized words. In other words, vocalization, from the age of 10 , slows down the reading process: P12 > P11 > P13 (Figure 3). We recall that from the age of 
Table 5. Cronbach alpha of P1.

\begin{tabular}{ccc}
\hline Age & Number & Alpha \\
\hline 7.5 & 22 & 0.85 \\
8.5 & 21 & 0.76 \\
9.5 & 25 & 0.89 \\
10.5 & 22 & 0.91 \\
11.5 & 26 & 0.92 \\
\hline
\end{tabular}

Table 6. The coefficients of the split half method of P1 by age.

\begin{tabular}{|c|c|c|c|c|c|c|c|}
\hline \multicolumn{3}{|c|}{ Reliability statistics of $\mathrm{P} 1=(\mathrm{P} 11 . \mathrm{P} 12 . \mathrm{P} 13) / 3$} & 7.5 & 8.5 & 9.5 & 10.5 & 11.5 \\
\hline \multirow{2}{*}{\multicolumn{2}{|c|}{ Partie 1}} & Valeur & 0.796 & 0.898 & 0.872 & 0.960 & 0.958 \\
\hline & & Nombre d'éléments & $2^{\mathrm{a}}$ & $2^{\mathrm{a}}$ & $2^{\mathrm{a}}$ & $2^{\mathrm{a}}$ & $2^{\mathrm{a}}$ \\
\hline \multirow[t]{3}{*}{ Alpha de Cronbach } & \multirow{2}{*}{ Partie 2} & Valeur & 1.000 & 1.000 & 1.000 & 1.000 & 1.000 \\
\hline & & Nombre d'éléments & $1^{\mathrm{b}}$ & $1^{\mathrm{b}}$ & $1^{\mathrm{b}}$ & $1^{\mathrm{b}}$ & $1^{\mathrm{b}}$ \\
\hline & \multicolumn{2}{|c|}{ Nombre total d'éléments } & 3 & 3 & 3 & 3 & 3 \\
\hline \multicolumn{3}{|c|}{ Corrélation entre les sous-échelles } & 0.763 & 0.379 & 0.755 & 0.742 & 0.820 \\
\hline \multirow{2}{*}{$\begin{array}{l}\text { Coefficient de Spear- } \\
\text { man-Brown }\end{array}$} & & teur égale & 0.865 & 0.549 & 0.860 & 0.852 & 0.901 \\
\hline & Lol & eur inégale & 0.877 & 0.570 & 0.872 & 0.864 & 0.910 \\
\hline \multicolumn{3}{|c|}{ Coefficient de Guttman split-half } & 0.670 & 0.477 & 0.698 & 0.635 & 0.636 \\
\hline
\end{tabular}

${ }^{\mathrm{a}}$ The elements are: P11, P12. ${ }^{\mathrm{b}}$ The elements are: P12, P13.

Table 7. Percentile ranks of P1.

\begin{tabular}{cccccccc}
\hline Age & 5 & 10 & 25 & 50 & 75 & 90 & 95 \\
\hline 7.5 & 9.6 & 10.7 & 15.9 & 18.6 & 21.4 & 26.0 & 32.0 \\
8.5 & 15.3 & 17.7 & 23.5 & 26.9 & 36.8 & 45.0 & 53.8 \\
9.5 & 15.6 & 23.7 & 28.2 & 32.5 & 41.5 & 50.9 & 52.5 \\
10.5 & 22.5 & 28.4 & 32.5 & 40.6 & 50.1 & 57.6 & 62.1 \\
11.5 & 23.6 & 30.8 & 42.6 & 54.1 & 62.5 & 69.5 & 79.3 \\
\hline
\end{tabular}

Table 8. The minimum thresholds of the P11, P12, P13 and P1.

\begin{tabular}{ccccc}
\hline Age & P1 & P11 & P12 & P13 \\
\hline 7.5 & 13.0 & 13.1 & 10.7 & 13.8 \\
8.5 & 20.6 & 18.3 & 21.0 & 15.6 \\
9.5 & 26.3 & 22.5 & 31.5 & 21.6 \\
10.5 & 30.6 & 29.2 & 35.1 & 25.3 \\
11.5 & 40.3 & 38.8 & 49.1 & 30.6 \\
Total & 21.2 & 19.2 & 22.9 & 19.0 \\
\hline
\end{tabular}

10 , the school program presents more and more non-vocalized texts at the expense of vocalized texts. This result contradicts the results obtained by Abu Ra- 
biaa and Abu Rahmoun in 2012 (Abu-Rabia \& Abu-Rahmoun, 2012), AbuRabiaa and Taha in 2006 (Abu-Rabia \& Taha, 2006), which revealed that the reading of the subject is more accurate in the vowel word recognition test than in tests without vowels knowing that time is not counted.

On the other hand, the acquisition of reading pseudo words follows a slower pace while respecting the monotony of growth with age. For this reading, there would be the inhibitory factor that is added because the items evoke words that the subject already recognizes and would tend to produce them rather than the pseudo-words that occur. However, for the first two groups (7.5 and 8.5), it is slightly higher than the vocalized reading.

\section{3) Impact of gender and type of school on the reading words}

Literacy skills are steadily increasing for all populations (regardless of gender and type of school), with some slight shifts in values across age groups (Figure 4).

Two decreases are recorded for girls (10.5 slices) and for private schools (9.5 slices).

The public school is more efficient in reading the Arabic language than the private school. This observation is explained by the fact that the private school strengthens the learning of the French language to the detriment of the Arabic language. This is not the case for the public school.

\section{4) Reliability indices}

The alpha coefficient of Cronbach: Alpha coefficients estimates the internal consistency of the test, based on the covariance between its items (Cronbach, 1951).

The values of the P1 by age group are calculated from the elements constituting it (sub-tests $\mathrm{P} 11, \mathrm{P} 12$ and $\mathrm{P} 13$ ). As shown in Table 5, these values range from 0.76 to 0.92 ; they are all greater than 0.7 . We can therefore confirm that they are acceptable and therefore the reliability of the P1 test is statistically satisfactory.

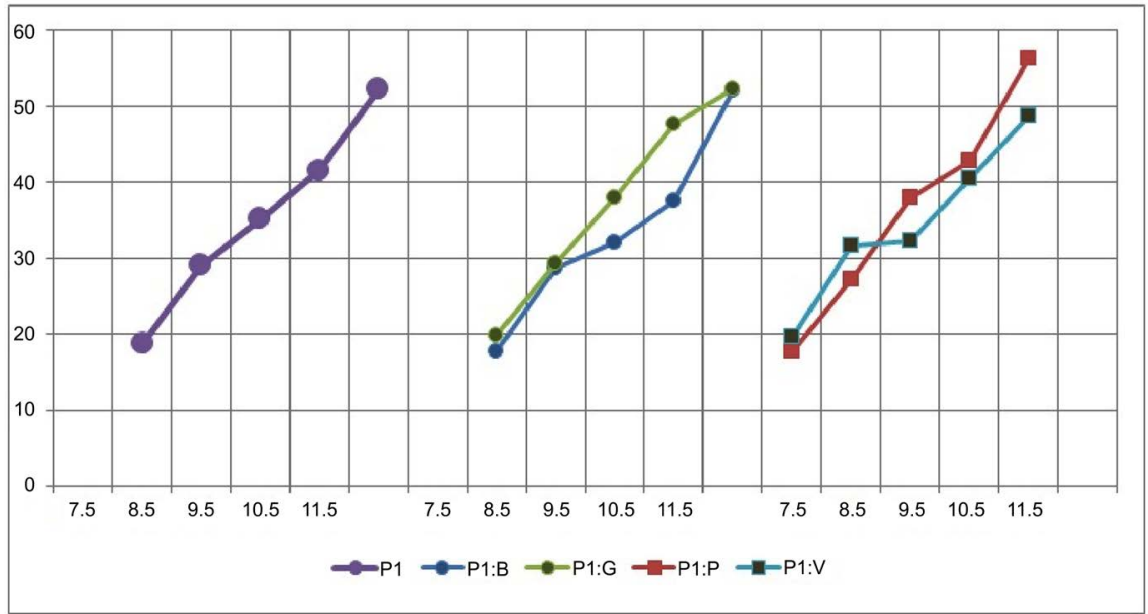

Figure 4. Comparative evolution of P11, P12, P13 by gender and type of school. 
The split-half method: P1 building elements considered in this method are those used for the method alpha Cronbach. They measure the internal homogeneity of the test. The values of the Spearman-Brown and Gultman correlation coefficients are not very small and therefore acceptable (Table 6).

The internal correlations methods: The elements of P1 test are sufficiently correlated $(r>0.77)$ to consider that they measure the same construct. The correlation coefficients determined show values $(r(\mathrm{P} 11, \mathrm{P} 12)=0.932, r(\mathrm{P} 11, \mathrm{P} 13)$ $=0.777$ and $r(\mathrm{P} 12, \mathrm{P} 13)=0.784)$ are very close to 1 .

\section{5) Validity indices}

The validity method based on the test relation retest.

a) The graphic presentation (Figure 5 and Figure 6), displays, that the majority of the points are located above the 1 st bisector. This is explained by the fact that the measures have improved, because of the repetition of the subtests on the one hand, and the progress made by learning this inter-sessional period on the other hand. Moreover, the linearity relation is maintained.

b) The test/retest correlation coefficients, determined for the reduced sample, show values very close to $1,(r(\mathrm{P} 11)=0.95, r(\mathrm{P} 12)=0.92, r(\mathrm{P} 13)=0.75$ and $r$ $(\mathrm{P} 1)=0.92)$. These results confirm that the validity based on the retest is very satisfactory.

\section{6) Norms}

Percentile ranks were extracted as norms for the raw scores of the standardization sample $(n=116)$. They are used because they are easy to calculate and interpret, and they are also good indicators of the individual's relative position in his group. The Table 7 shows the percentile ranks for each age group of P1.

The purpose of this evaluation is to identify if the child has a reading disability in Arabic. The determination of a lower limit threshold largely meets this need.

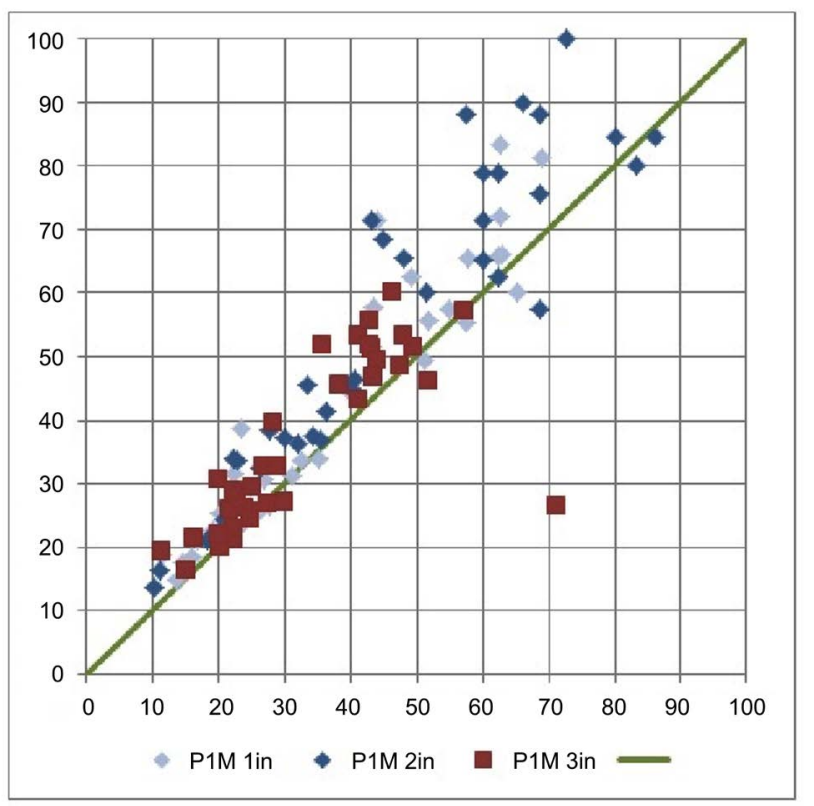

Figure 5. Cloud of P1 retest vs initial measures. 


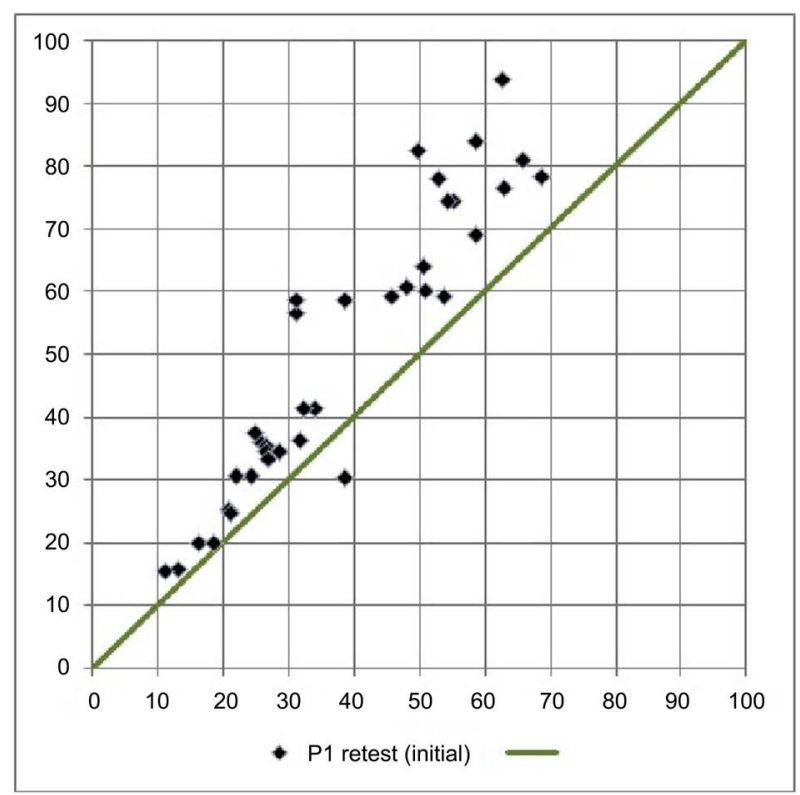

Figure 6. Cloud of P11, P12, P13 retest vs initial measures.

The lower risk thresholds, by age group, are determined from the means by deducting one unit of standard deviation $(z=-1)$ (Table 8).

The gender and type of school factors have little or no influence on the measures, so they were not considered in this calculation. The Table 8 shows the thresholds for each reading subtest as well as for the overall test P1, P11, P12, P13.

The calculation of the $z$-score makes it possible to appreciate its distance from the mean of the measurements in terms of standard deviation. This transformation provides information on the extent of its performance or difficulty.

\section{Discussion}

In the present study, the process of deducing statistical data on the reading of test scores revealed that the Moroccan children's scores were nearly similar to the normal distribution. This, in turn, may be considered as the norm for judging the representation of the population to which the results are intended to generalize.

The estimated reliability coefficients of the standardization sample in this study were high and acceptable (Table 5, Table 6). In addition, all of the validity's indices in this study were found to be acceptable.

We propose and discuss 3 ways to apply the norms:

\section{Application 1:}

Since we have standards for this test, its utilization would allow health professionals, general practitioners, child psychiatrists, pediatricians, neuropsychologists and speech-language pathologists to detect dysfunctions in the treatment of written language in primary school children.

The results of the test would also guide the follow-up of the reeducation. 


\section{Application 2:}

The evolution of the three subtests and P1 is similar, this led us to analyze their collinearity. The values of P11 (vocalized words) are very close to those of the global reading $(\mathrm{P} 1)$.

The different clouds of points P1 (P11), P12 (P11), and P13 (P11) show that they are successively collinear (Figure 7 ). The high values of the correlation coefficients and the determination of the linear regression confirm these dependencies. In the case of normal-reading children, the reading of vocalized words (P11) could be representative and explanatory of other aspects of reading.

$$
\begin{aligned}
& \mathrm{P} 1=0.93 \times \mathrm{P} 11+3.47(r=0.97) \\
& \mathrm{P} 12=1.17 \times \mathrm{P} 11+1.59(r=0.93) \\
& \mathrm{P} 13=0.61 \times \mathrm{P} 11+8.84(r=0.79)
\end{aligned}
$$

We could apply these equations in two different ways:

In the case where the readings measurements of the, P12, P13, P1 are not available, we could estimate them from the only measurement of P11.

In the case where all the measurements are evaluated, the comparison of the real values and the estimated values would make it possible to situate the performance of the various aspects of the reading.

Example (Table 9):

Child without dysfunction. Measured P11 $=44.5$ then

Child with dysfunction. Measured P11 = 18.4

\section{Application 3:}

The P1 test was administered to a population of 16 children diagnosed dyslexic by speech therapists in the Rabat region.

According to the thresholds defined above, we note that all the children failed the P1 test, one of them succeed only the subtest P13.

Both addressing and assembly pathways are corrupted. They are deep dyslexic children (the $z$ mean varied from -2.18 to -2.53 ) (Table 10). The maximum values of $Z$ are less than -1 , except for the P13 test for one child. This one has surface dyslexia, the addressing is disrupted but the assembly pathway is
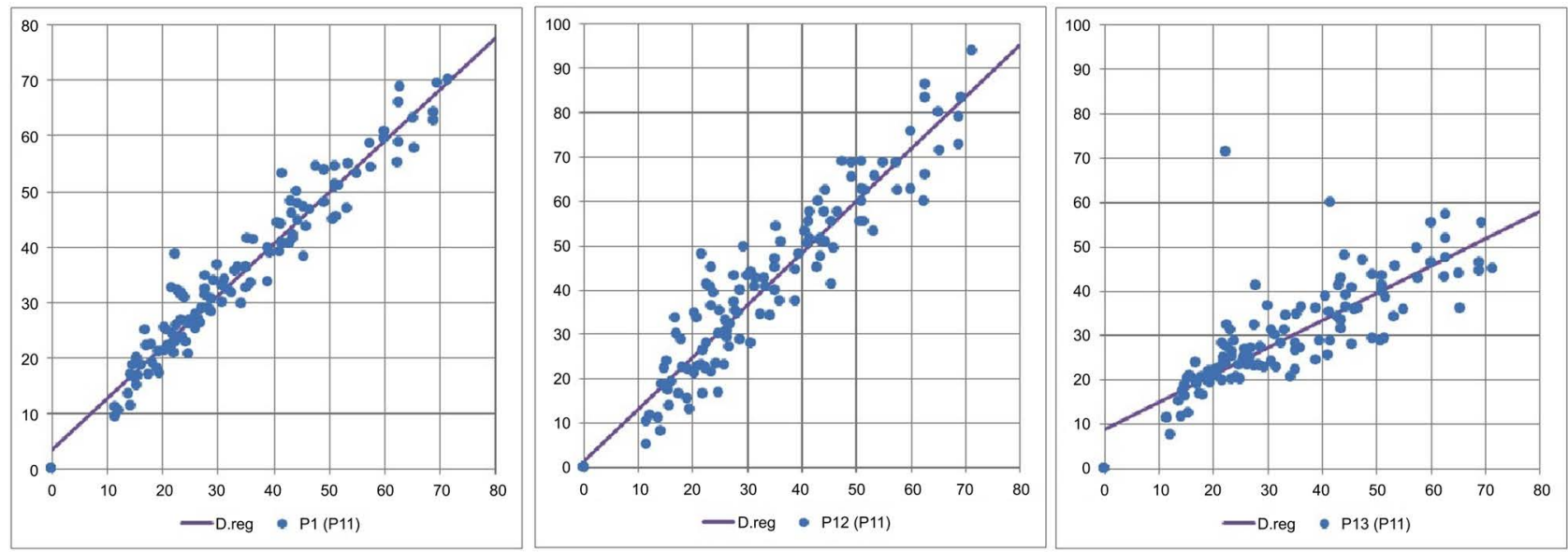

Figure 7. Linear regression of $\mathrm{P} 1, \mathrm{P} 12$ and $\mathrm{P} 13$ as a function of $\mathrm{P} 11$. 
Table 9. Estimation of measurements of P12, P13 and P1 from P11.

\begin{tabular}{ccccccc}
\hline & \multicolumn{3}{c}{ Child without dysfunction } & \multicolumn{3}{c}{ Child with dysfunction } \\
\hline & measured & calculated & difference & measured & calculated & difference \\
\hline P11 & 44.5 & & & 18.4 & & \\
P12 & 50.7 & 53.7 & 2.9 & 8.05 & 23.19 & 15.14 \\
P13 & 38.9 & 35.9 & -2.9 & 14.07 & 20.10 & 6.03 \\
P1 & 44.7 & 44.8 & 0.1 & 13.53 & 20.64 & 7.11 \\
\hline
\end{tabular}

Table 10. Deficiency of language therapy in dyslexic children.

\begin{tabular}{cccccc}
\hline Test & deficit & $Z$ least & $Z$ mean & $Z$ highest & Z st \\
\hline P1 & $16(100 \%)$ & -4.11 & -2.24 & -1.29 & 0.71 \\
P11 & $16(100 \%)$ & -3.67 & -2.53 & -1.70 & 0.57 \\
P12 & $16(100 \%)$ & -3.73 & -2.36 & -1.16 & 0.70 \\
P13 & $15(94 \%)$ & -3.84 & -2.18 & -0.71 & 0.77 \\
\hline
\end{tabular}

preserved with the success of the P13 subtest.

We note that all children have failed P12 subtest, and therefore in this sample, we did not encounter phonological dyslexics whose address path is preserved and the assembly pathway is impaired.

\section{Conclusions}

The present study provides normative data regarding the performance of Moroccan children aged 7 - 12 years in task of Recognition the Written Words.

All dyslexic children have a deficiency in the reading of both vocalized and non-vocalized words (confirmed by the linear dependence of scores for both normal and dyslexic populations).

This test should be used, first of all, by the doctor and the neuropsychologist, to assess the presence of learning disabilities in the processing of the Arabic language. Then, the analysis of the results, could help the speech therapist, to develop a program of care for the children having these difficulties.

The Ministry of Education could benefit from this study and generalize it to other Moroccan regions. Comparative analysis of these statistical results could highlight and compare their level of performance in reading.

In the end, this study could be considered as a pilot project for all Arabic-speaking countries.

\section{References}

Abo Ras, Y., Kozou, H., \& Abdou, R. (2008). Development of an Arabic Test for Assessment of Dyslexia in Egyptian Children (Vol. 44). Alexandria.

Abu-Rabia, S. (1996). The Role of Vowels and Context in the Reading of Highly Skilled Native Arabic Readers. Journal of Psycholinguistic Research, 25, 629-641.

https://doi.org/10.1007/BF01712413 
Abu-Rabia, S. (1998). Reading Arabic Texts: Effects of Text Type, Reader Type and Vowelization. Reading and Writting, 10, 105-119. https://doi.org/10.1023/A:1007906222227

Abu-Rabia, S., \& Abu-Rahmoun, N. (2012). The Role of Phonology and Morphology in the Development of Basic Reading Skills of Dyslexic and Normal Native Arabic Readers. Creative Education, 3, 1259-1268. https://doi.org/10.4236/ce.2012.37185

Abu-Rabia, S., \& Taha, H. (2006). Reading in Arabic Orthography: Characteristics, Research Findings, and Assessment. University of Haifa

Ammar, M. (1998). Les Strategies D'Identification De Mots Ecrits En Arabe. Nantes.

Ammar, M. (2002). L'assemblage phonologique: Sa nature et son fonctionnement chez des enfants lecteurs en arabe. Enfance, 54, 155-168. https://doi.org/10.3917/enf.542.0155

APA (2013). Diagnostic and Statistical Manual of Mental Disorders (5th ed.). Washington.

Cronbach, L. J. (1951). Coefficient Alpha and the Internal Structure of Tests. Psychometrika, 16, 297-334. https://doi.org/10.1007/BF02310555

Écalle, J. (2010). L'évaluation de la lecture et des compétences associées. Revue Française de Linguistique Appliquée, XV, 105-120.

Fletcher, J. M. (2009). Dyslexia: The Evolution of a Scientific Concept. Journal of the International Neuropsychological Society, 15, 501-508.

https://doi.org/10.1017/S1355617709090900

Forum Mondial sur la dyslexie (2010).

Geva, E., Wade-Woolley, L., \& Shany, M. (1997). Development of Reading Efficiency in First and Second Language. Scientific Studies of Reading, 1, 119-144. https://doi.org/10.1207/s1532799xssr0102_2

Goswami, U., Ziegler, J. C., Dalton, L., \& Schneider, W. (2003). Nonword Reading across Orthographies: How Flexible Is the Choice of Reading Units? Applied Psycholinguistics, 24, 235-247.

Grégoire, J., \& Laveault, D. (2014). Introduction aux théories de tests en psychologie et en sciences de l'éducation (3e Édition).

Jacquier-Roux, M., Valdois, S., \& Zorman, M. (2002). Odédys: Outil de dépistage des dyslexies. Grenoble: L. Cogni-Sciences, Ed.

Marec-Breton, N., Gombert, J. E., \& Colé, P. (2005). Traitements morphologiques lors de la reconnaissance des mots écrits chez des apprentis lecteurs. L'Année Psychologique, 105, 9-45. https://doi.org/10.3406/psy.2005.3818

Reid Lyon, G., E. Shaywitz, S., \& Shaywitz, B. (2003). A Definition of Dyslexia. Annals of Dyslexia, 53, 1-14. https://doi.org/10.1007/s11881-003-0001-9

Romdhane, M. N., Gombert, J.-É., \& Belajouza, M. (2003). L'Apprentissage de la lecture Perspectives comparatives (Presses un).

Share, D. L. (1995). Phonological Recoding and Self-Teaching: Sine Qua Non of Reading Acquisition. Cognition, 55, 151-218. https://doi.org/10.1016/0010-0277(94)00645-2

Snowling, M. (1988). Cognitive Analysis of Dyslexia. By P. H. K. Seymour. (pp. 265; $£ 26.50$.) Routledge \& Kegan Paul: London. 1986. Psychological Medicine, 18, 243-244. https://doi.org/10.1017/S0033291700002105

Sprenger-Charolles, L., Colé, P., Béchennec, D., \& Kipffer-Piquard, A. (2005). French Normative Data on Reading and Related Skills from EVALEC, a New Computerized Battery of Tests (End Grade 1, Grade 2, Grade 3, and Grade 4)1. Revue Européenne de 
Psychologie Appliquée/European Review of Applied Psychology, 55, 157-186. https://doi.org/10.1016/j.erap.2004.11.002

Zagar, D., Fayol, M., Gombert, J.-E., Lecoq, P., \& Sprenger-Charolles, L. (1994). Psychologie cognitive de la lecture. Revue Française de Pédagogie, 107, 150-153.

Ziegler, J., Perry, C., \& Zorzi, M. (2014). Modelling Reading Development through Phonological Decoding and Self-Teaching: Implications for Dyslexia. Philosophical Transactions of the Royal Society of London. Series B, Biological Sciences, 369, Article ID: 20120397. 